\title{
Çocuk ve ergen psikiyatrisi polikliniğine başvuran hastaların başvuru biçimi, şikayet, tanı ve eştanı dağılımları
}

\section{Assessment of symptoms, diagnosis and comorbidity of patients referring to a child and adolescent psychiatry outpatient clinic}

\section{Burcu ERSÖZ ALAN*}

Hacettepe Üniversitesi Tıp Fakültesi Çocuk ve Ergen Ruh Sağlığı ve Hastalıkları Anabilim Dalı, Ankara/TÜRKiYE

\section{Öz}

Amaç: Çocuk ve ergen psikiyatrisine aile, genç kendi isteğiyle veya başka birimlerin yönlendirmesiyle başvurabilir. Bu çalışmada çocuk ve ergen psikiyatrisi başvurularının, tanı ile eştanının birden çok başvuru şikayetine göre değerlendirilmesi amaçlanmıştır.

Gereç ve Yöntemler: Nisan 2017-Mart 2018 tarihlerinde Kırıkkale Üniversitesi Çocuk ve Ergen Psikiyatrisi polikliniğine ayaktan başvuruların dosyası geriye dönük olarak incelenmiştir.

Bulgular: $\% 63,5^{\prime}$ i erkek, yaş ortalaması $9,2 \pm 4,0$ yıl olan 1079 hastanın dosyasından okul çağında erkeklerin, ergenlikte kızların daha fazla başvurduğu; okulun erkekleri, pediatrinin kızları daha sık yönlendirdiği; ergen kızların kendi isteğiyle başvurabildiği saptanmıştır. Okul tarafından dışa vurum şikayetleri; pediatri tarafından nörogelişimsel sorunlar ve somatik belirtiler belirtilmiştir. Erkeklerde hareketlilik, sinirlilik/laf dinlememe, konuşma/telaffuz sorunları, konuşmama/ geç konuşma; kızlarda somatik yakınmalar, mutsuzluk/kolay ağlama, kendine zarar verme davranışı/intihar girişimi daha fazladır. Birden fazla şikayet erkeklerde daha fazladır. \%75,3'ü en az bir tanı almıştır. Erkeklerde Dikkat Eksikliği Hiperaktivite Bozukluğu (DEHB), iletişim bozuklukları, otizm spektrum bozukluğu; kızlarda depresyon, ayrılık anksiyetesi bozukluğu daha fazladır $(p<0,05)$. Erkeklerin \%17,7'si, kızların \%12,7'si eştanı almıştır ( $p<0,05)$. Eştanı sıklığı okul öncesinde \%5,2, okul çağında \%19,2, ergenlikte \%19,5 şeklindedir. İkinci şikayet belirtenlerin \%86, $5^{\prime i}$ eştanı almıştır ( $\left.p<0,05\right)$. En fazla eştanı DEHB ve zihinsel yetersizlikte saptanmıştır.

Sonuç: Bulgular literatürle uyumludur. Bu çalışmanın çocuk ve ergen psikiyatrisinde bölge özelliklerine göre hasta profilinin oluşturulmasına, koruyucu ve tedavi edici hizmetlerin planlanmasına katkı sağlayacağı düşünülmektedir. Yapılandırılmış ölçeklerle epidemiyolojik verilerin toplanması önerilmektedir.

Anahtar kelimeler: Çocuk; ergen; psikiyatri; şikayet; tanı; eştanı

Sorumlu Yazar*: Burcu Ersöz Alan, Hacettepe Üniversitesi Tıp Fakültesi Çocuk ve Ergen Ruh Sağlığı ve Hastalıkları Anabilim Dalı, Ankara/TÜRKiYE E-posta: burcuersoz02@gmail.com

ORCID: 0000-0002-3704-0722

Gönderim: 11.01.2019 kabul: 01.04.2019

Doi: $10.18663 /$ tjcl.511659 


\begin{abstract}
Aim: Referrals to child and adolescent psychiatry may be due to the family, school, the teenager's own request or other units like paediatrics. In this study, it was aimed to evaluate child and adolescent psychiatry applications, diagnosis and comorbidities according to multiple referral complaints.
\end{abstract}

Material and Methods: Medical records of 1079 patients referred to the Child and Adolescent Psychiatry outpatient clinic at Kirikkale University, between April 2017 and March 2018 were evaluated retrospectively.

Results: Most of the cases were boys (63.5\%) and mean age was $9.2 \pm 4.0$ years. Boys were mostly at school aged. Adolescent girls could apply due to their own request. School directed mostly for externalizing problems, peadiatrics directed mostly for neurodevelopmental problems and somatic complatins. Hyperactivity, nervousness, speech problems/delay were common in boys; somatic complaints, unhappiness/easy crying, self-harm behavior/suicide attempt were common in girls. More than one complaint was seen mostly in boys. $75.3 \%$ of patients had at least one diagnosis. Attention deficit hyperactivity disorder (ADHD), communication disorders and autism spectrum disorder were common in boys, depression, seperation anxiety disorder were common in girls. $17.7 \%$ of boys and $12.7 \%$ of girls had comorbidites. The rate of comorbidity was $86.5 \%$ in the presence of more than one complaints $(p<0.05)$. The diagnosis rate of comorbidities were $5.2 \%$ in preschool patients, $19.2 \%$ in school aged patients and $19.5 \%$ in adolescent patients. They were mainly in ADHD and intellectual disability group.

Conclusion: The findings were consistent with the literature. This study would contribute to the improvement of child and adolescent psychiatry services and may be beneficial for preventive mental health. It is recommended to collect epidemiological data with structured scales.

Key words: Child; adolescent; psychiatry; symptom; diagnosis; comorbidity

\section{Giriş}

Dünyada çocuk ve ergenlerde psikiyatrik bozukluk görülme prevalansı \%13,4; yaş grupları arasında okul öncesi dönemde $\% 8$, okul çağı döneminde $\% 12$ ve ergenlik döneminde $\% 15$ oranında saptanmıştır [1,2]. Çocuk ve Ergen Psikiyatrisi polikliniklerine başvurular ailenin, gencin kendi isteğiyle ya da okul, pediatri gibi birimlerin yönlendirmesiyle olabilmektedir. Değerlendirmede çocuk ve ergen biyopsikososyal açılardan bütüncül olarak ele alınmalıdır [3]. Çocuğun yaşadığı bölge başvuru biçimini, koruyucu ve tedavi edici ruh sağlığı hizmetlerinin planlanmasını etkiler.

Psikiyatrik bozukluklarda eştanı oranının fazla olması ve belirtilerin örtüşmesi nedeniyle başvurular birden fazla şikayetle olabilmektedir. Çalışmaların çoğunda başvuru şikayetlerinin sadece biri değerlendirilmiştir. Bu çalışma ile çocuk ve ergen psikiyatrisi başvurularının, tanı ile eştanının birden çok başvuru şikayetine göre değerlendirilmesi amaçlanmıştır.

\section{Gereç ve Yöntemler}

Nisan 2017-Mart 2018 tarihleri arasında Kırıkkale Üniversitesi Tıp Fakültesi Çocuk ve Ergen Psikiyatrisi Anabilim Dalı polikliniğine ayaktan başvuran 1197 hastanın dosyası geriye dönük olarak incelenmiştir. Adli vakalar (s:20), başka bir merkezin takibinde olup ilaç yazdırmaya gelen hastalar (s:15), sağlık kurulu raporuna itiraz sonucu başvuran hastalar (s:13) ve yaşam olaylarına (kardeş doğumu, boşanma, vefat gibi) dair danışmanlık almak için gelen aileler (s:70) çalışmaya dahil edilmemiştir. Çalışma için Kırıkkale Üniversitesi Girişimsel Olmayan Klinik Araştırmalar Etik Kurulu'ndan onay alınmıştır. Psikiyatrik tanılar ve eştanılar Ruhsal Bozuklukların Tanısal ve Sayımsal El Kitabı Beşinci Baskısı'nda (Amerikan Psikiyatri Birliği 2013) (DSM-5) yer alan ölçütlere uygun yapılan klinik görüşme ve gerektiğinde istenilen ölçeklerle (öğretmen formu gibi) testlerin (gelişim testi, zeka testi gibi) sonuçlarına göre konulmuştur [4]. Hastaların cinsiyet ve yaş (0-5,9, 6-11,9, 12-17,9 yıl) grupları belirlenmiştir. Başvurmalarına neden olan en önemli ilk iki şikayet göz önüne alınmıştır. Birincil tanılar işlev kaybına en çok neden olan ve klinik seyri en çok etkileyen şikayet ile şikayetlerin başlangıç zamanı göz önünde bulundurularak belirtilerin tümünü kapsayan tanının saptanmasıly konulmuştur. Diğer belirti ve bulgulara göre ikincil tanılar belirlenmiştir.

Veriler Sosyal Bilimler İçin İstatistik Paket Programı (Statistical 
Package for Social Sciences (SPSS) 21) kullanılarak analiz edilmiştir. Tüm veriler tanımlayıcı istatistiksel yöntemlerle (sayı, yüzde, ortalama, standart sapma) değerlendirilmiştir. Kategorik verilerin değerlendirilmesinde ki-kare testi, numerik verilerin değerlendirilmesinde t-testi kullanılmıştır. İstatistiksel anlamlılık sınırı $p<0,05$ olarak kabul edilmiştir.

\section{Bulgular}

1197 hastadan 118 hasta çalışmaya dahil edilmemiştir. Yaş ortalaması 9,2 \pm 4,0 yıl olan \%63,5'i erkek (s:685) 1079 hastanın sosyodemografik verileri Tablo 1'de belirtilmiştir.

\begin{tabular}{|c|c|c|c|c|c|}
\hline \multirow{3}{*}{ Yaş (yıl) } & \multicolumn{2}{|c|}{ Erkek } & \multicolumn{2}{|c|}{ Kız } & \multirow{3}{*}{$\begin{array}{c}\mathbf{p} \\
<0,05 z\end{array}$} \\
\hline & \multicolumn{2}{|c|}{$\begin{array}{l}8,7 \pm 3,8(\min : \\
1,4, \max : 17,5)\end{array}$} & \multicolumn{2}{|c|}{$\begin{array}{c}10,0 \pm 4,2 \text { (min: } \\
1,5, \max : 17,6)\end{array}$} & \\
\hline & s & $\%$ & s & $\%$ & \\
\hline \multicolumn{6}{|l|}{ Yaş Dönemi } \\
\hline Okul Öncesi (0-5.9 y) & 181 & 26,4 & 86 & 21,8 & 0,107 \\
\hline Okul Çağı (6-11.9 y) & 357 & 52,1 & 147 & 37,2 & $<0,05$ \\
\hline Ergen (12-17.9 y) & 147 & 21,5 & 161 & 40,8 & $<0,05$ \\
\hline \multicolumn{6}{|l|}{ Yaşadığı il } \\
\hline Kırıkkale & 595 & 86.9 & 351 & 88,8 & 0,388 \\
\hline Kırıkkale Dışı & 90 & 13.1 & 44 & 11,2 & \\
\hline Yönlendiren Birim & 668 & 97,5 & 386 & 98,0 & \\
\hline Anne & 287 & 41,9 & 173 & 43,9 & 0,129 \\
\hline Baba & 51 & 7,4 & 23 & 5,8 & 0,527 \\
\hline Anne ve Baba & 155 & 22,6 & 74 & 18,8 & 0,345 \\
\hline Okul & 123 & 18,0 & 38 & 9,6 & $<0,05$ \\
\hline Pediatri & 21 & 3,1 & 30 & 7,6 & $<0,05$ \\
\hline Kendisi & 10 & 1,5 & 30 & 7,6 & $<0,05$ \\
\hline Diğer* & 20 & 2,9 & 16 & 4,1 & 0,170 \\
\hline
\end{tabular}

Erkeklerin 262 (\%38,2), kızların 131 (\%33,2)'inin başvurusunda birden fazla şikayet belirtilmiştir (p:0,101). Hareketlilik (s:80), ders sorunları (s:61), dikkatsizlik (s:48), sinirlilik/laf dinlememe (s:45), korku/endişeler (s:34), mutsuzluk (s:20) en sık belirtilen şikayetlerdir. Erkekler arasında hareketlilik (s:66, \%9,6), ders sorunları (s:46, \%6,7), dikkatsizlik (s:35, \%5,1), sinirlilik/laf dinlememe (s:33, \%4,8); kızlar arasında korku/endişeler (s:18, $\% 4,6)$, ders sorunları (s:15, \%3,8), mutsuzluk (s:15, \%3,8) en sık belirtilen ikinci şikayetlerdir. Yaş gruplarına göre ikinci şikayet sıklığı okul çağı (s:221, \%43,8), ergenlik (s:134, \%43,5) ve okul öncesi (s:38, \%14,2) şeklindedir; ikinci şikayet oranı her yaş grubunda anlamlı olarak düşüktür $(p<0,05)$. Okul öncesi dönemde kızlarda \%9,3 (s:8), erkeklerde \%16,6 (s:30); okul döneminde kızlarda \%42,9 (s:63), erkeklerde \%44,3 (s:158) ve ergenlik döneminde kızlarda \%37,3 (s:60), erkeklerde \%50,3 (s:74) oranında ikinci şikayet belirtilmiştir; her yaş grubunda cinsiyetler arasındaki fark anlamlı bulunmuştur $(p<0,05)$ (Tablo 2, Tablo 3).

Anne ve baba tarafından sinirlilik/laf dinlememe (s:35, \%15,3), konuşmama/geç konuşma (s:35, \%15,3), hareketlilik (s:32, $\% 14,0)$ ve ders sorunları $(s: 26, \% 11,4)$ başta olmak üzere her türlü şikayet dile getirilmiştir. Erkekler konuşmama/ geç konuşma (s:33), hareketlilik (s:29), ders sorunları (s:18), sinirlilik/laf dinlememe (s:18); kızlar sinirlilik/laf dinlememe $(\mathrm{s}: 17)$, ders sorunları (s:8) nedeniyle getirilmiştir. Anne ve baba tarafından getirilen erkek hastaların \%38,1'i (s:59) okul öncesi, \%46,5'i (s:72) okul çağı, \%15,5’i (s:24) ergenlik döneminde; kızların \%35,1'i (s:26) okul öncesi, \%41,9’u (s:31) okul çağı ve \%23'ü (s:17) ergenlik dönemindedir. Okul öncesi 17 (\%10,6), okul çağında $109(\% 67,7)$ ve ergenlik döneminde $35(\% 21,7)$ hasta okul tarafından yönlendirilmişlerdir. Pediatri tarafından ise $8(\% 15,7)$ okul öncesi, $20(\% 39,2)$ okul çağı ve $23(\% 45,1)$ ergenlik döneminde olan hasta yönlendirilmiştir. Okulun erkekleri ders sorunları (s:40), hareketlilik (s:33), sinirlilik/laf dinlememe (s:17), geç algılama (s:14), kızları ders sorunları (s:11), geç algılama (s:7) ve dikkatsizlik (s:6) nedeni ile; pediatri tarafından ise erkeklerin kaka kaçırma (s:4), geç konuşma (s:3) ile, kızların somatik yakınmalar (s:14), kaka kaçırma (s:3) nedeniyle yönlendirildikleri saptanmıştır. (Tablo 1)

Hastaların \%75,3'üne (s:813) en az bir tanı konulmuştur. (Tablo 4) Okul öncesi dönemde $123(\% 46,4)$, okul çağında $87(\% 17,5)$ ve ergenlik döneminde $56(\% 18,4)$ hasta herhangi bir tanı almamıştır; her üç yaş grubunda da tanı alma oranı anlamlı olarak daha fazladır $(p<0,05)$. Kızlarda her yaş grubunda tanı almama oranı daha fazladır $(p<0,05)$. Yaş dönemine göre tanı almama oranları şunlardır: Okul öncesi (E:73 (\%40,8), K:50 $(\% 58,1))$; okul çağı (E:58 (\%16,4); K:29 (\%20,1)) ve ergenlik (E:18 (\%12,3), K:38 (\%23.9)). (Tablo 5, Tablo 6)

Okul tarafından yönlendirilen hastaların 143'üne $(\% 88,8)$, pediatri tarafından yönlendirilen hastaların 30'una $(\% 60,0)$ tanı konulmuştur; her ikisinde de tanı alma oranı anlamlı olarak yüksektir $(p<0,05)$. Okulun yönlendirmesiyle başvuranlara DEHB (E:64, \%52,0; K:11, \%28,9) ve zihinsel yetersizlik (ZY) (E:24, $\% 19,5 ; \mathrm{K}: 8, \% 2,1)$ en sık konulan tanılar olmuştur. Pediatrinin yönlendirmesiyle başvuran erkeklerin 7'si (\%33,3), kızların 13'ü $(\% 44,8)$ herhangi bir tanı almamıştır. Kendi isteği ile başvuran erkekler konuşma/telaffuz soruları (s:2), çekingenlik (s:2), mutsuzluk (s:2); kızlar mutsuzluk/kolay ağlama (s:6), somatik yakınmalar (s:4), korku/endişe (s:3), Kendine zarar verme davranışı (s:3), dikkatsizlik (s:2), ders sorunları (s:2), okuldan / evden kaçma (s:2), sinirlilik (s:2) şikayetlerini dile getirmişlerdir. 


\begin{tabular}{|c|c|c|c|c|c|c|c|}
\hline \multirow[b]{2}{*}{ Birinci Başvuru Şikayeti } & \multicolumn{2}{|c|}{ Erkek } & \multicolumn{2}{|c|}{$\mathbf{K} \mathbf{\prime z}$} & \multicolumn{2}{|c|}{ Toplam } & \multirow[t]{2}{*}{$\mathbf{p}$} \\
\hline & $\mathrm{s}$ & $\%$ & $\mathrm{~s}$ & $\%$ & $\mathrm{~s}$ & $\%$ & \\
\hline Hareketlilik & 111 & 11,6 & 18 & 4,6 & 129 & 12,0 & $<0,05$ \\
\hline Sinirlilik/ Laf dinlememe & 106 & 15,5 & 57 & 14,5 & 163 & 15,1 & 0,724 \\
\hline Ders sorunları & 96 & 14 & 50 & 12,7 & 146 & 13,5 & 0,508 \\
\hline Konuşma/Telaffuz sorunları & 60 & 8,8 & 15 & 3,8 & 75 & 7,0 & $<0,05$ \\
\hline Konuşmama/ Geç konuşma & 56 & 8,2 & 9 & 2,3 & 65 & 6,0 & $<0,05$ \\
\hline Dikkatsizlik & 37 & 5,4 & 27 & 6,9 & 64 & 5,9 & 0,350 \\
\hline Korku/Endişe & 33 & 4,8 & 24 & 6,1 & 57 & 5,3 & 0,397 \\
\hline Geç algılama & 31 & 4,5 & 15 & 3,8 & 46 & 4,3 & 0,641 \\
\hline Somatik yakınmalar & 24 & 3,5 & 38 & 9,6 & 62 & 5,7 & $<0,05$ \\
\hline Uyku sorunları & 17 & 2,5 & 9 & 2,3 & 26 & 2,4 & 1,0 \\
\hline Alıskanlıklar (Tırnak yeme, parmak emme, mastürbasyon) & 16 & 2,3 & 16 & 4,1 & 32 & 3,0 & 0,135 \\
\hline Çekingenlik & 16 & 2,3 & 16 & 4,1 & 32 & 3,0 & 0,135 \\
\hline Kaka kaçırma & 14 & 2,0 & 12 & 3,0 & 26 & 2,4 & 0,309 \\
\hline Okuldan/Evden kaçma & 11 & 1,6 & 14 & 3,6 & 25 & 2,3 & 0,057 \\
\hline Tik & 10 & 1,5 & 6 & 1,5 & 16 & 1,5 & 1,0 \\
\hline İnternette/telefonla uzun zaman geçirme & 8 & 1,2 & 2 & 0,5 & 10 & 0,9 & 0,342 \\
\hline İdrar kaçırma & 8 & 1,2 & 4 & 1,0 & 12 & 1,1 & 1,0 \\
\hline Mutsuzluk/Kolay ağlama & 8 & 1,2 & 26 & 6,6 & 34 & 3,2 & $<0,05$ \\
\hline Takıntı/İstenmeyen düşünce & 7 & 1,0 & 9 & 2,3 & 16 & 1,5 & 0,118 \\
\hline Arkadaş sorunları (zorbalığa maruz kalma, küskünlük) & 7 & 1,0 & 6 & 1,5 & 13 & 1,2 & 0,564 \\
\hline Kendine zarar verme/Intihar girişimi & 2 & 0,3 & 12 & 3,0 & 14 & 1,3 & $<0,05$ \\
\hline $\begin{array}{l}\text { Diğer (yemek sorunları, saç yolma, özbakımını ihmal etme, karşı } \\
\text { cins davranışları gösterme, tedavi uyumsuzluğu) }\end{array}$ & 7 & 1,0 & 9 & 2,3 & 16 & 1,5 & 0,118 \\
\hline
\end{tabular}

\begin{tabular}{|c|c|c|c|}
\hline Cinsiyet & Okul Öncesi (s) & Okul Çağı (s) & Ergenliği (s) \\
\hline \multirow{5}{*}{ Erkek } & Konuşmama/Geç konuşma (43) & Hareketlilik (75) & Ders sorunları (29) \\
\hline & Konuşma/Telaffuz sorunları (37) & Ders sorunları (65) & Sinirlilik/Laf dinlememe (28) \\
\hline & Sinirlilik/Laf dinlememe (31) & Sinirlilik/Laf dinlememe (47) & Hareketlilik (16) \\
\hline & Hareketlilik (20) & Dikkatsizlik (26) & Dikkatsizlik (9) \\
\hline & Alışkanlıklar* (8) & Korku/Endişe (22) & Somatik yakınmalar (9) \\
\hline \multirow{5}{*}{ Kiz } & Sinirlilik/Laf dinlememe (20) & Ders sorunları (31) & Somatik yakınmalar (27) \\
\hline & Konuşma/Telaffuz sorunları (11) & Sinirlilik/Laf dinlememe (21) & Mutsuzluk/Kolay ağlama (26) \\
\hline & Alışkanlıklar* (11) & Dikkatsizlik (19) & Ders sorunları (18) \\
\hline & Hareketlilik (7) & Hareketlilik (9), & Sinirlilik/Laf dinlememe (16) \\
\hline & Konuşmama/ Geç konuşma (6) & Somatik yakınmalar (9), Geç algılama (9) & Korku/Endişe (14) \\
\hline
\end{tabular}

$121(\% 17,7)$ erkek ve $50(\% 12,7)$ kız eştanı almıştır $(p<0,05)$. Eştanı sıklığı okul öncesinde \%5,2 (s:14), okul çağında \%19,2 (s:97), ergenlikte \%19,5 (s:60) şeklindedir. İkinci şikayet belirtenlerin 148'i $(\% 86,5)$ 'eştanı almıştı $(p<0,05)$. Erkeklerde ve kızlarda en fazla eştanı DEHB ve ZY'de saptanmıştır. Erkeklerde DEHB'ye en sık KOKGB (s:24), özgül öğrenme bozukluğu (ÖÖB) (s:7) ve ZY (s:4); kızlarda ÖÖB (s:6), ZY (s:2), karşıt olma karşı gelme bozukluğu (KOKGB) (s:2) eşlik etmiştir. ZY'ye erkeklerde DEHB (s:12) ve davranım bozukluğu (s:5), kızlarda DEHB (s:3) eşlik etmiştir. Kızlarda depresyonla görülen eştanı sayısı fazlayken (KOKGB, anksiyete bozukluğu diğer, tik bozuklukları, Enürezis nokturna ve ayrlık anksiyetesi bozukluğu) erkeklerde sınırda zeka düzeyi ile birlikte görülen eştanı sayısı (ÖÖB, DEHB, KOKGB, sosyal anksiyete bozukluğu, enürezis nokturna) fazladır. Yaş gruplarına göre en sık konulan eştanılar şunlardır: okul öncesi dönemde KOKGB (s:3), otizm spektrum bozukluğu (s:2); okul çağı döneminde KOKGB (s:20), DEHB (s:17), ÖÖB (s:15), ZY (s:8); ergenlik döneminde DEHB (s:10), KOKGB (s:10), davranış bozukluğu (s:8). Eştanı almayan tanılar anoreksiya nervosa, psikotik durumlar, trikotilomani, alışanlık bozuklukları, uyku bozuklukları, cinsiyet disforisi ve temaruzdur. 


\begin{tabular}{|c|c|c|c|}
\hline Cinsiyet & Okul Öncesi (s) & Okul Çağı (s) & Ergenliği (s) \\
\hline \multirow[t]{5}{*}{ Erkek } & İletişim bozuklukları (34) & DEHB (145) & DEHB (44) \\
\hline & OSB (20) & ZY (30) & ZY (20) \\
\hline & $\mathrm{DEHB}(12)$ & OSB (11), Sınırda zeka düzeyi (11) & Depresyon (13) \\
\hline & $Z Y(10)$ & Kekemelik (10), Uyum Bozukluğu (10) & Yok (18) \\
\hline & Enkoprezis (6) & YAB (10) & \\
\hline \multirow{5}{*}{ Kız } & Yok (73) & Yok (58) & \\
\hline & İletişim bozuklukları (9) & DEHB (36) & Depresyon (41) \\
\hline & $\mathrm{AAB}(7)$ & ZY (18) & YAB (10) \\
\hline & Yok (50) & Depresyon (7), Anksiyete bzk, diğer (7) & $\begin{array}{l}\text { DEHB (9), ZY (9), Anksiyete } \\
\text { bzk, diğer (9) }\end{array}$ \\
\hline & & Yok (29) & Yok (38) \\
\hline
\end{tabular}

\section{Tartışma}

$\mathrm{Bu}$ çalışma genelinde erkeklerin başvurusu daha fazladır; okul çağında erkekler, ergenlik döneminde kızlar daha fazla başvurmuştur. Okulun erkekleri, pediatrinin kızları yönlendirdiği; kendi isteğiyle başvuru oranının ergen kızlarda daha fazla olduğu saptanmıştır. Ülkemizdeki çalışmalarda erkeklerin ve 6-12 yaş okul dönemi çocuklarının daha çok başvurduğu saptanmıştır [5-16]; sadece bir çalışmada 1218 yaş grubu daha fazla başvurmuştur [17]. Yurt dışında da erkeklerin daha fazla başvurduğu saptanmıştır [18]. Erkeklerde her yaş döneminde dışa vurum davranışları, okul öncesi dönemde gelişimsel sorunlar fazladır. Bu durum dışa vurum davranışlarının erkeklerde daha sık görülüp kolay saptanması ve erkeklerin nörogelişimlerinin kızlardan yavaş olması ile ilişkili olabilir [19]. Kendi isteği ile başvuran kızların mutsuzluk/kolay ağlama, somatik yakınmalar ve korku/endişeler gibi içe vurum sorunlarının ön planda olması, bu sorunların fark edilememesi nedeniyle kendilerinin psikiyatriye başvurarak yardım arayışında bulunmalarına yol açabilir. Bu çalışmada annebaba tarafından başvurma ergenlik döneminde erkeklerde \%15,5'e karşın kızlarda \%23'tür. Erkeklerin aileleri tarafından ikna edilip getirilebilme intimallerinin ergenlikte azabileceği düşünülmektedir. Ayrıca genelde psikiyatrik bozukluklar erkeklerde çocukluk, kızlarda ise ergenlik döneminde başlar [19]. Psikiyatri polikliniklerine başvurulardaki cinsiyet farklıı̆̆ı erişkinlikte de devam etmektedir; bu durum kadınların damgalanma endişesi hissetmeden psikiyatrik sorunlarını daha az inkar etmelerine, daha fazla psikolojik açıklık göstererek yardım arayışında bulunmalarına bağlanmışır [20]. Bu çalışmada okulun dışa vurum şikayetleri nedeniyle erkekleri yönlendirdiği gözlenmiştir. Dışa vurum belirtileri öğretmenlerce kolay fark edilir. Okullarda içe vurum sorunlarını tanımaya yönelik eğitimlerle farkındalık arttırılabilir. Çocuk ve ergen psikiyatrisinde tanı koymada ve tedavide okuldan alınan bilgi önemlidir.
Karakoç Demirkaya ve ark. (2015) pediatri ve diğer bölümlerce yönlendirilme oranını $\% 11,2$ olarak belirtirken bu çalışmada sadece pediatri tarafından yönlendirilme oranı \%4,2'dir [17]. Pediatri tarafindan nörogelişimsel sorunlarve somatikbelirtiler, özelliklekaka kaçırma ve konuşma gecikmesi yönlendirilmiş̧ir. Pediatriye erişim nispeten kolay olduğundan pediatristlerin psikiyatrik bozukluklarla ilgili farkındalığı arttııımalıdır [21]. Psikiyatri belirtilerini tarayan ölçeklerin pediatride kullanılması araştırımıştır [22]. Aile ve hastanın niyeti olmadan psikiyatriye yönlendirmenin başvuruya ve tedavi uyumuna etkisi tartışmalıdır [23].

Bu çalışmada birden fazla şikayetle başvurma oranı erkeklerde daha fazladır. Çalışmalarda birden fazla şikayetin dile getirilme oranlarında, cinsiyetler arasında fark olmadığı belirtilmiştir $[8,11,13]$; ayrıca birden çok şikayet ile ilaç kullanımı arasında ilişki saptamıştır [13]. Literatürde erkeklerde kekemelik ile hareketlilik, kızlarda mutsuzluk ile fiziksel yakınmalar; her iki cinsiyette hareketlilik, sinirlilik ve ders başarısızlığı ön plandadır $[6,9,11,13]$. Hareketlilik en çok dile getirilen şikayetler arasındadır. Bu durum ailelerin baş etme becerisinin yetersizliğine, yaş dönemi özellikleri konusunda yeterli bilgiye sahip olmamasına, sınır koyma sorunlarına, DEHB ile ilgili farkındalığın artmasına bağlı olabilir. Erkeklerde okul öncesinde konuşma gecikmesi sık saptanmıştır. Nörogelişimsel olgunlaşmanın gecikmesi, OSB farkındalığının artması, artmış ekran maruziyeti ve uyaran eksikliği bu sonuca yol açabilir. Bu çalışmada kız ergenlerde hareketlilik şikayeti daha az, içe vurum sorunları daha fazla saptanmıştır; ergenlerle yapılan çalışmalarla uyumludur [24,25]. Tanı çeşitliliği, sinirlilik/ laf dinlememe ve ders sorunları şikayetlerinde fazladır. Bir şikayetin çoğunlukla birden fazla tanı ile ilişkili olabileceği gösterilmiştir $[8,11,12,25,26]$. Bu çalışmada ders sorunlarına eşlik eden ikincil şikayetler fazladır. Pek çok durumun sonucu olan ders başarısızlığı çocuğun motivasyonunu kırıp benlik 
saygısını etkiler, ailesiyle arasında sorunlara neden olur. Tedavi risk etkenleri ve eştanılar saptanarak planlanmalı; okulun desteği alınmalıdır. Psikiyatride tanının anamneze dayalı olması, kesin tanıyı koymak için belirteç veya ölçeğin kullanılamaması nedeniyle şikayetler detaylandırımalı, ilişkili tüm bozukluklar taranmalıdır. Çocuklarda psikiyatrik bozuklukların en sık görülme yaşı 9-10 yaştır [27]. Bu çalışmada da tanı alma oranı en fazla okul çağı dönemindedir. Akademik başarıda, sorumluluk duygusu ve sosyal ortamlara uyumda becerilerin beklentilerin altında olmasıyla sorunlar fark edilmektedir.

Bu çalışmada her yaş gurubunda kızlarda tanı almama oranı erkeklerden daha düşük bulunurken kızların ergenlikte tanı alma oranı diğer yaş dönemlerine göre daha fazladır. Bu durum ergenlikte kızların başvurularındaki artışla ve psikiyatrik bozuklukların kızlarda sıklıkla ergenlik döneminde başlamasıyla uyumludur [19]. Okul öncesi dönemde herhangi bir tanı alma oranı diğer yaş dönemlerine göre daha düşük bulunmuştur (E \%59,2, K \%42,9). Tanı alma oranını Sevgen ve Altun (2017) 0-5 yaş arasında \%71,6; Çoşkun ve Kaya (2016) ise 3-6 yaş arasında \%41,7 olarak bildirmişler $[15,28]$. Ülkemizde yapılan çalışmalarda çocuk ve ergen psikiyatrisi başvurularında tanı almama oranı \%3,3 ile \%25,3 arasındadır [8-10,12]. Psikiyatriye dair farkındalık ve kültürel yargıların bölgesel farkılık göstermesi nedeniyle hasta profilinin farklıığı, çalışmalarda metodun aynı olmaması tanı oranını değiştirmektedir. Ayrıca çocuk ve ergenlerde saptanan belirtinin şiddetinin ve sayısının tanı koymak için yeterli olamayabileceği; ancak bu çocuklara da ihtiyaç duydukları müdahaleyi uygulamak gerektiği belirtilmektedir [29].

Ülkemizdeki diğer çalışmalara benzer şekilde bu çalışmada da en sık konulan tanılar DEHB, ZY, herhangi bir anksiyete bozukluğu olmuştur [7,10,12,13,15]. Literatürde tanı dağılımı erkeklerde DEHB ve diğer dışa vurum bozuklukları, kızlarda ise anksiyete bozuklukları, depresyon gibi içe vurum bozuklukları şeklindedir $[9,10,13,14]$. Okul öncesi dönemde iletişim bozuklukları, okul döneminde $D E H B$ ve $Z Y$, ergenlik döneminde ise erkeklerde DEHB, kızlarda depresyon en sık saptanan tanılardır. Okul öncesi dönemde iletişim bozukluklarının DEHB ile ilişkili olabileceği gösterilmiştir [30]. Bu çalışmada erkeklerde okul öncesi dönemde iletişim bozuklukları, okul döneminde DEHB sıktır; iletişim bozukluğu tanılı çocukların DEHB yönünden izlenmesi önerilir. 4 yaşındaki çocuklarda psikiyatrik tanının 10 yaşında sürekliliğini araştıran bir çalışmada, psikiyatrik bozuklukların ilerleyen yıllarda aynı kalabildiği gibi başka psikiyatrik bozukluklara da dönüşebildiği belirtilmiştir [31]. Yaş grupları arasındaki belirti ve tanı farklılıklarının nedenlerinden biri bu olabilir. Okul öncesi dönemde saptanan bozuklukların izlenmesinde akılda tutulmalıdır.
Tedaviye uyumu ve yanıtı etkilemeleri nedeniyle eştanıların tespit edilmesi önemlidir. Psikiyatride eştanı oranının \%45'lere vardığı belirtilmiştir [32]. Bu çalışmada eştanı oranı erkeklerde daha fazladır. KOKGB her yaş grubunda eştanı olarak saptanmıştır. Her iki cinsiyette de en sık DEHB ve ZY eştanı almıştır. Ülkemizdeki çalışmalarda eştanı oranı metadolojik farklılıklara bağlı olarak \%10-\%49 arasında değişmektedir; en fazla eştanı DEHB'de saptanmıştır [6,8,12-16]. Bu çalışmada sınırda zeka düzeyine DEHB, DEHB'ye sınırda zeka düzeyinin sık eşlik etmesi gibi karşılıklılık göze çarpmaktadır. Ayrıca farklı tanılar çok benzer şikayetlere neden olmaktadır. Psikiyatride eştanının çok yaygın olmasıyla ilgili çeşitli hipotezler öne sürülmektedir; sık birliktelik gösteren bozuklukların aynı spektrumun ve aynı yatkınlığın bir parçası olması ya da tanı kriterlerinin belirsizliği ve çakışması bu hipotezlerdendir $[32,33]$. Bu çalışmada eştanıların karşılıklılığı, farklı tanılarda şikayetlerin benzerliği ilgili hipotezlerle uyumludur.

Çalışmada ölçek verilerinin kullanılmamış olması, geriye dönük dosya bilgilerinin taranması çalışmanın kısıtlılıklarındandır. Tek bir ildeki veriler genelleştirmeyi engellemektedir. Ancak bu çalışma Kırıkkale ilinde çocuk ve ergen psikiyatrisi ile ilgili yapılan ilk çalışmadır; ülkemizde çocuk ve ergen ruh sağlığı hizmetlerin planlanmasına katkı sağlayacağı düşünülmektedir. Bölgesel farklılıklar göz önüne alınarak çocuklara, ergenlere ve onlarla etkileşen mesleklere psikiyatrik farkındalığın arttırılmasına yönelik eğitimlerin hazırlanmasının koruyucu ruh sağlığı açısından faydalı olacağı düşünülmektedir. Yapılandırılmış ölçeklerle yurt genelinde epidemiyolojik verilerin toplanması önerilmektedir.

\section{Çıkar çatışması / finansal destek beyanı}

Bu yazıdaki hiçbir yazarın herhangi bir çıkar çatışması yoktur. Yazının herhangi bir finansal desteği yoktur.

\section{Kaynaklar}

1. Polanczyk GV, Salum GA, Sugaya LS, Caye A, Rohde LA. Annual Research Review: A meta-analysis of the worldwide prevalence of mental disorders in children and adolescents. J Child Psychol Psychiatry 2015; 56: 345-65.

2. Roberts RE, Attkisson CC, Rosenblatt A. Prevelance of psychopathology among children and adolescents. Am J Psychiatry 1998; 155: 715-25.

3. Rutter M, Silberg J, O'Connor T. Genetics and child psychiatry. I. Advances in quantitative and molecular genetics. J Child Psychol Psychiatry 1999; 40:3-18.

4. Amerikan Psikiyatri Birliği. Mental Bozuklukların Tanısal ve Sayımsal El Kitabı, Beşinci baskı (DSM 5), Tanı Ölçütleri Başvuru Elkitabı'ndan, çev.: Köroğlu E, Hekimler Yayın Birliği, Ankara, 2013. 
5. Avcı A. AÜTF Çocuk Psikiyatrisi kliniğine başvuran hastaların belirti dağılımı ve sosyodemografik özellikleri. Ankara Üniversitesi, Yayınlanmamış Tıpta Uzmanlık Tezi. 1992.

6. Tanrı̈ver S, Kaya N, Tüzün Ü, Aydoğmuş K. Çocuk psikiyatrisi polikliniğine başvuran çocukların demografik özellikleri ile ilgili bir çalışma. Düşünen Adam Psikiyatri Nöroloji Bilim Derg 1992; 5: 13-19.

7. Abalı O, Durukan M, Mukaddes NM, Polvan O. Çocuk psikiyatrisi polikliniğine başvuran hastaların sosyodemografik özelliklerine göre değerlendirilmesi. Haseki Tıp Bülteni 2006; 44: 1-7.

8. Aras Ş, Ünlü G, Taş FV. Çocuk ve ergen psikiyatrisi polikliniğine başvuran hastalarda belirtiler, tanılar ve tanıya yönelik incelemeler. Klin Psikiyatr Derg 2007; 10: 28-37.

9. Aktepe E, Demirci K, Çaliskan AM, Sönmez Y. Symptoms and diagnoses of patients referring to a child and adolescent psychiatry polyclinic. Dusunen Adam J Psychiatry Neurologic Sciences 2010; 23: 100-108.

10. Durukan I, Karaman D, Kara K, Türker T, Tufan A E, Yalçın Ö, Karabekiroglu K. Diagnoses of patients referring to a child and adolescent psychiatry outpatient clinic. Dusunen Adam J Psychiatry Neurologic Sciences 2011; 24: 113-20.

11. Fidan YT. Bir çocuk-ergen ruh sağlığı ve hastalıkları polikliniğine başvuran çocuk ve ergenlerin ruhsal belirtileri ve risk faktörlerinin değerlendirilmesi. Konuralp Tıp Dergisi 2011; 3: 1-8.

12. SarıBA. Batman'da çocuk psikiyatrisi polikliniğine başvuran hastalarda belirti ve tanı dağılımları. Klin Psikiyatr Derg 2013; 16: 7-17.

13. Uçar HN, Vural AP, Kocael Ö, Köle IH, Dağdelen F, Kırtıl IY. Bir çocuk ve ergen psikiyatrisi polikliniğine başvuran hastaların yakınma, tanı ve ilaç uygulamaları karakteristiklerinin değerlendirilmesi. Uludağ Üniv Tıp Fak Derg 2014; 40: 75-83.

14. Türkoğlu S. Çocuk ve Ergen Psikiyatrisi Polikliniğine Başvuran Hastalarda Tanı Dağılımları. Selçuk Tıp Derg 2014; 30: 118-122.

15. Çoşkun M, Kaya I. Psikiyatri kliniğine başvuran okul öncesi çocuklarda psikiyatrik bozuklukların yaygınlığı ve örüntüleri. Anadolu Kliniği 2016; 21: 42-47.

16. Gormez V, Orengul AC, Baljinnyam S, liyeva N. Diagnostic and demographic characteristics of patients referred to a child and adolescent psychiatry clinic. JMOOD 2017; 7: 41-46.

17. Demirkaya Karakoç S, Aksu H, Yılmaz N, Özgür BG, Eren E, Avcil SN. Bir üniversite hastanesi çocuk ve ergen psikiyatrisi polikliniğine başvuran olguların tanıları ve sosyodemografik özellikleri. Meandros Med Dent J 2015; 16: 4-8.

18. Harpaz-Rotem I, RosenheckRA.Changes in outpatient psychiatric diagnosis in privately insured children and adolescents from 1995 to 2000. Child Psychiatry Hum Dev 2004; 34: 329-340.
19. Zahn-Waxler C, Shirtcliff EA, Marceau K. Disorders of childhood and adolescence: Gender and psychopathology. Annu Rev Clin Psychol 2008; 4: 275-303.

20. Mackenzie CS, Gekoski WL, Knox VJ. Age, gender, and the underutilization of mental health services: the influence of helpseeking attitudes. Aging Ment Health 2006; 10: 574-82.

21. Costello EJ. Primary care pediatrics and child psychopathology: $A$ review of diagnostic, treatment, and referral practices. Pediatrics 1986; 78:1044-51.

22. Jellinek MS, Murphy JM, Robinson J, Feins, A., Lamb S, Fenton T. Pediatric symptom checklist: Screening school-age children for psychosocial dysfunction. J Pediatr 1988; 112: 201-209.

23. Hacker K, Arsenault L, Franco I, Shaligram D, Sidor M, Olfson M, Goldstein J. Referral and follow-up after mental health screening in commercially insured adolescents. J Adolesc Health 2014; 55: 17-23.

24. Görker I, Korkmazlar Ü, Durukan M, Aydoğdu A. Çocuk ve Ergen Psikiyatri Kliniğine Başvuran Ergenlerde Belirti ve Tanı Dağılımı. Klin Psikiyatr Derg 2004; 7: 103-10.

25. Akdemir D, Çuhadaroğlu Çetin F. Çocuk ve ergen psikiyatrisi bölümüne başvuran ergenlerin klinik özellikleri. Çocuk Genç Ruh Sağlığı Derg 2008; 15(1): 5-13.

26. Öner Ö, Öncü B, Sağduyu G, Canat S. Dikkatsizlik yakınması ile başvuran ergenlerin aldıkları tanılar. Çocuk Genç Ruh Sağlığı Derg 2002: 9; 167-71.

27. Costello EJ, Mustillo S, Erkanli A, Keeler G, Angold A. Prevalence and development of psychiatric disorders in childhood and adolescence. Arch Gen Psychiatry 2003; 60: 837-44.

28. Sevgen FH, Altun H. Çocuk ve Ergen Psikiyatrisi Polikliniğine Başvuran 0-5 Yaş Arası Çocukların Başvuru Şikayetleri ve Psikiyatrik Tanıları. JMOOD 2017; 7: 205-11.

29. World Health Organization. Child and Adolescent Mental Health Policies and Plans. WHO Library Cataloguing-in-publication Data. Mental Health Policy and Services Guidance Package, 2005

30. Geurts HM, Embrechts M. Language profiles in ASD, SLI, and ADHD. J Autism Dev Disorders 2008; 38: 1931-43.

31. Wichstrøm L, Belsky J, Steinsbekk S. Homotypic and heterotypic continuity of symptoms of psychiatric disorders from age 4 to 10 years: a dynamic panel model. J Child Psychol Psychiatry 2017; 58: 1239-47.

32. Caspi A, Moffitt TE. All for one and one for all: Mental disorders in one dimension. Am J Psychiatry 2018; 175: 831-44.

33. Van Loo HM, Romeijn JW. Psychiatric comorbidity: fact or artifact?. Theor Med Bioeth 2015; 36: 41-60. 